\title{
MEMBANGUN KREATIVITAS ANAK DARI SEGI KOGNISI DAN AGAMA
}

\author{
Dzatil Husni \\ Dosen STAI Darun Najah Jakarta
}

\begin{abstract}
Abstrak
Anak memiliki kecenderungan bakat dan minat tertentu, namun hendaknya orang tua tetap mengarahkan anak ke jalan yang benar menurut agama, karena dunia hanya tempat singgah sementara, ada kampung akhirat yang lebih abadi untuk ditinggali, kendatipun demikian manusia tidak boleh melupakan nasibnya di dunia (QS. al-Qashash [28]: 77). Maka kewajiban orang tua menyiapkan anak untuk memiliki bekal menjadi manusia yang bermutu sesuai dengan kualifikasi mutu yang diminta dunia dan akhirat. Karena jika manusia ingin bahagia dunia akhirat hendaklah ia menguasai ilmu mengenai keduanya.

kreativitas bukanlah sesuatu yang given, melainkan harus diupayakan untuk memilikinya, ada proses belajar yang harus dilewati, ada pengetahuan yang harus dikuasai sebagai basic dari kreativitas itu, juga kreativitas membutuhkan kemauan/ desire. Kreativitas timbul sebagai usaha memahami dan mengatasi kesenjangan/ kesulitan hidup. Kreativitas berfungsi ketika manusia bertingkah laku berevolusi, menyesuaikan diri terhadap perubahan alam. Berarti dibutuhkan will dalam membangun kreativitas. Bisa dipahami juga bahwa kreativitas hanya bisa dimiliki oleh mereka yang mempunyai curiosity. Curiosity itu yang menjadi pendorong untuk bisa melakukan sesuatu demi mengatasi kondisi tertentu.
\end{abstract}

Kata Kunci: membangun, kreativitas anak, kognisi, agama

\section{A. Pendahuluan}

Menciptakan suatu hal yang baru kadang bisa dikatakan sulit, kadang mudah. Ketika manusia dihadapkan pada sesuatu yang membuatnya berfikir, maka manusia dengan kelebihan istimewa yang diberikan Allah, yaitu akalnya, akan mencoba berbagai cara menemukan solusi. Salah satu contoh, sepeda. Sejarah sepeda bermula di Inggris tahun 1790, dengan nama Hobby Horses dan Celeriferes. Keduanya belum punya mekanisme sepeda zaman sekarang, batang kemudi dan sistem pedal. Hanya ada dua roda pada sebuah rangka kayu. Penemuan fenomenal dalam kisah masa lalu sepeda tercipta berkat Baron Karl Von Drais. Von Drais yang berhasil melakukan terobosan penting pada tahun 
1817, merupakan peletak dasar perkembangan sepeda selanjutnya. Oleh Von Drais, Hobby Horse dimodifikasi hingga mempunyai mekanisme kemudi pada bagian roda depan. Ia menyebutnya Draisienne. Proses penciptaan selanjutnya dilakukan Kirkpatrick Macmillan. Pada tahun 1839, ia menambahkan batang penggerak yang menghubungkan antara roda belakang dengan ban depan Draisienne. Untuk menjalankannya, tinggal mengayuh pedal yang ada. James Starley mulai membangun sepeda di Inggris di tahun 1870. Starley berhasil membuat terobosan dengan mencipta roda berjari-jari dan metode cross-tangent. Sampai kini, kedua teknologi itu masih terus dipakai. Sampai akhirnya, keponakan James Starley, John Kemp Starley melanjutkan karyanya. Ia menciptakan sepeda yang lebih aman untuk dikendarai oleh siapa saja pada 1886. Sepeda ini sudah punya rantai untuk menggerakkan roda belakang dan ukuran kedua rodanya sama. Namun penemuan tak kalah penting dilakukan John Boyd Dunlop pada 1888. Dunlop berhasil menemukan teknologi ban sepeda yang bisa diisi dengan angin (pneumatic tire). Sejak ini sepeda makin menemukan kesempurnaannya hingga sekarang. ${ }^{1}$

Mengapa membicarakan sejarah sepeda? Bukan lampu, mesin uap, telepon dan lainnya? Poin penting dalam sejarah penemuan apapun, adalah ide dan kreativitas. Bagaimana seorang manusia biasa menjadi luar biasa dengan ide yang muncul, dan tidak sebatas itu, ia berusaha untuk mewujudkan ide-ide itu ke alam nyata. Sesuatu yang tadinya mungkin tidak pernah terbayangkan oleh orang-orang pada zaman itu, namunmelalui ide dan kreativitas yang istimewa-kemudian "sesuatu" itu tercipta dan berkembang hingga akhirnya dinikmati oleh puluhan bahkan ratusan generasi setelahnya. Lalu, apa dan bagaimana kreativitas itu, dan bagaimana membangun sisi kreatif anak hingga ia bisa menemukan "sesuatu" yang berguna bagi umat manusia di kemudian hari? Akan dibahas secara sekilas pada tulisan berikut.

\section{B. Makna Kreativitas}

Para pakar membedakan pengertian kreativitas, beberapa diantaranya: Barron ${ }^{2}$ mengatakan bahwa kreativitas adalah kemampuan untuk menciptakan sesuatu yang baru. Makna 'baru' di sini menurut Utami3 ${ }^{3}$, tidaklah menciptakan dari yang tidak ada menjadi ada, melainkan mewujudkan suatu kombinasi yang sudah ada sebelumnya.

Sedikit lebih panjang Drevdahl menjelaskan bahwa kreativitas adalah kemampuan untuk memproduksi komposisi-komposisi dan gagasan-gagasan baru yang dapat berwujud aktivitas imajinatif dan sintesis yang mungkin melibatkan pembentukan pola-pola

\footnotetext{
${ }^{1}$ http://adesuryana.blogspot.com/2009/02/sejarah-sepeda.html

2 Barron, R. and R. Woods, An Introduction toPhilosophy of Education, (London: Methuen, 1982), hlm. 253

3 Utami Munandar, Mengembangkan Bakat dan Kreativitas Anak Sekolah, (Jakarta: Gramedia Widiasarana Indonesia, 1992), hlm. 47
} 
baru dan kombinasi dari pengalaman masa lalu yang dihubungkan dengan yang sudah ada pada situasi sekarang. Hasil tersebut berguna, bertujuan, terarah, dan tidak hanya sekedar fantasi. Sumber awal dari perkembangan kreativitas itu disebabkan oleh faktorfaktor yang ada dalam lingkungan keluarga ${ }^{4}$.

Sementara Rhodes mengelompokkan kreativitas dalam empat kategori, yaitu product, person, process, dan press. Product menekankan kreativitas dari hasil karya kreatif, baik yang sama sekali baru maupun kombinasi karya-karya lama yang menghasilkan sesuatu yang baru. Person memandang kreativitas dari segi ciri-ciri individu yang menandai kepribadian orang kreatif atau yang berhubungan dengan kreativitas, ini dapat terlihat melalui perilaku yang nampak. Process menekankan bagaimana proses kreatif itu berlangsung sejak dari mulai tumbuh sampai dengan terwujudnya perilaku kreatif. Sedangkan press menekankan pada pentingnya faktor-faktor yang mendukung timbulnya kreativitas pada individu ${ }^{5}$.

Beralih ke Torrance, ia mengatakan bahwa kreativitas adalah kemampuan memahami kesenjangan-kesenjangan atau hambatan-hambatan dalam hidupnya, merumuskan hipotesis-hipotesis baru, dan mengkomunikasikan hasil-hasilnya, serta sedapat mungkin memodifikasi dan menguji hipotesis- hipotesis yang telah dirumuskan. Kemampuan kreatif ini menurut Torrance berlangsung melalui proses belajar yang dilakukan oleh individu dalam waktu yang lama. Kemampuan ini juga membutuhkan pengetahuan sebagai bahan dalam membuat hipotesis-hipotesis baru terhadap sesuatu.

Dari perspektif psikologi, Maslow mengatakan kreativitas adalah kemampuan manusia mengarah/menuju pada penciptaan/penyusunan sesuatu yang berpola baru. Kreativitas merupakan tanda manusia mengaktualisasikan dirinya. Aktualisasi diri merupakan kebutuhan tertinggi manusia dalam piramida hierarki kebutuhan yang dikonsepkan Malsow. Aktualisasi diri masuk kepada kelompok B-Needs atau being needs: kebutuhan untuk menjadikan dirinya "ada", sedangkan empat kebutuhan sebelumnya berada pada kategori D-Needs atau deficit needs: yaitu kebutuhan dasar, yang apabila salah satunya tidak terpenuhi dengan imbang, maka manusia akan merasakan kekurangan dalam hidupnya, kebutuhan ini sebagai syarat terciptanya homeostatis. ${ }^{6}$

Sedangkan dari sudut filsafat, menurut Toety Heraty Noerhadi, kreativitas memiliki fungsi biologik dan evolusi budaya. ${ }^{7}$ Kreativitas berfungsi biologis ketika stimulus yang muncul direspon dengan sikap/gerakan fisik, sampai membentuk restrukturasi. Ini

\footnotetext{
${ }^{4}$ Hurlock, Elizabeth, Child Development, (Mc Graw Hill, 1978) 6 $6^{\text {th }}$ ed, hlm. 300

5 Torrance, E. P., The Faces and Forms of Creativity, (Buffalo: Creative Educational Foundation, 1981), hlm. 30

${ }^{6}$ Maslow, Abraham, Motivation and Personality, (New York: Harper, 1945), hlm. 60

7 Toety Heraty Noerhadi, "Kreativitas, Suatu Tinjauan Filsafat, dalam Kreativitas; Kumpulan Makalah Simposium Kreativitas Akademi Jakarta, S. Takdir Alisyahbana (ed.), (Jakarta: Dian Rakyat, 1983), disarikan dari hlm.11-17
} 
diawali dari "kondisioning klasik' sebagai tahapan pertama, yang diciptakan Ivan Pavlov dalam merangsang perilaku anjing melalui bunyi bel. Kondisioning klasik ini dilanjutkan oleh B.F. Skinner terhadap tikus-tikus percobaannya, untuk membedakan pintu yang berbagai bentuk dan warna, melalui proses yang disebut dengan conditioning operant. Tahap ketiga dalam hukum stimulus respon ini adalah kondisioning semantik yang sudah melibatkan bahasa dalam pemberian stimulus. Kondisioning semantik ini akhirnya meluas tidak sebatas bahasa saja melainkan juga mencakup simbol2 dan tanda-tanda, Karena manusia adalah makhluk yang sangat mahir dalam membentuk simbol-simbol dan tanda-tanda untuk menyampaikan makna. Simbol-simbol ini terus mengalami perubahan dan pembaharuan sesuai dengan pengertian-pengertian baru yang dipahami manusia mengenai segala hal. Tahapan pembaharuan ini merupakan tahapan yang terakhir yang dinamakan restrukturasi kreatif. Inilah posisi dan fungsi kreativitas tertinggi yaitu: mengganti tatanan lama dengan tatanan baru.

Kreativitas dalam fungsinya sebagai evolusi budaya. Sejak awal, manusia mengandalkan kemampuan berburu hewan dan bertahan hidup di hutan, namun kemudian ada perubahan situasi dimana manusia harus hidup berpindah-pindah dengan kondisi alam yang mungkin sama sekali berlainan dengan tempat hidup sebelumnya. Dalam kondisi seperti ini dituntut penyesuaian diri yang baik, maka manusia mencoba untuk menyesuaikan kemampuan hidupnya dengan tantangan baru, yang kemudian menimbulkan kreativitas dalam bekerja. Proses perubahan dari zaman batu ke zaman logam merupakan bukti dari kreativitas yang berfungsi sebagai evolusi budaya tersebut.

Terkait dengan budaya, Selo Soemardjan ${ }^{8}$ mengatakan bahwa, kreativitas selamanya tidak akan pernah berhenti dipengaruhi oleh kondisi budaya yang mengitari tempat kreativitas itu tumbuh. Budayapun memiliki faktor pembentuk yang beragam, ada yang timbul dari nilai-nilai, norma agama, aturan adat suku, tata nilai hukum dan nilai-nilai normative lainnya.

Dari beberapa definisi yang dipaparkan, ada beberapa hal penting yang bisa disarikan dari kreativitas bahwa; (1) Mengarah pada sesuatu yang baru, (2) Merupakan usaha untuk beradaptasi dengan kesulitan atau tuntutan, (3) Membutuhkan entri/ pengetahuan yang sudah ada sebelumnya/pengalaman, (4) Kreativitas bisa dipelajari, bukan hadiah dari Tuhan, (5) Lingkungan sangat mempengaruhi kemampuan kreativitas, (6) Kreativitas membutuhkan proses, bukan sesuatu yang langsung jadi dalam sekejap, (7) Kreativitas sebagai tanda kemampuan mengembangkan diri.

Dari pemahaman beberapa definisi ini bisa dimengerti bahwa, kreativitas bukanlah sesuatu yang given, melainkan harus diupayakan untuk memilikinya, ada proses belajar

8 Selo Soemardjan, "Kreativitas Dilihat Dari Sudut Pandang Sosiologi", dalam " Kreativitas; Kumpulan Makalah Simposium Kreativitas Akademi Jakarta", S. Takdir Alisyahbana (ed.), (Jakarta: Dian Rakyat, 1983), disarikan dari hlm. 93-94 
yang harus dilewati, ada pengetahuan yang harus dikuasai sebagai basic dari kreativitas itu, juga kreativitas membutuhkan kemauan/desire. Terlihat dari uraian Torrance, bahwa kreativitas timbul sebagai usaha memahami dan mengatasi kesenjangan/kesulitan hidup. Demikian pula yang digambarkan Sutan Takdir Alisyahbana, bahwa kreativitas berfungsi ketika manusia bertingkah laku berevolusi, menyesuaikan diri terhadap perubahan alam. Berarti dibutuhkan will dalam membangun kreativitas. Bisa dipahami juga bahwa kreativitas hanya bisa dimiliki oleh mereka yang mempunyai curiosity. Curiosity itu yang menjadi pendorong untuk bisa melakukan sesuatu demi mengatasi kondisi tertentu.

Apabila kreativitas bukanlah given by God, berarti keluarga memiliki peranan besar terhadap pertumbuhan jiwa kreativitas anak, seperti dikatakan Drevdahl, karena keluarga merupakan sekolah pertama bagi anak, maka pengaruh yang datang dari keluarga adalah pengaruh pertama yang akan membentuk/membantu perkembangan anak. Agar pengarahan/pengajaran materi apapun kepada anak bisa berhasil, termasuk didalamnya mengarahkan anak untuk kreatif, haruslah dimulai dari usia dini. Usia dini, seperti yang "dijual" di iklan-iklan, merupakan golden stage si anak, dimana sistem memorynya sangat mudah menerima dan merekam informasi apapun, sehingga materi apapun akan diterimanya dengan baik. Oleh karenanya penting bagi orang tua, keluarga dan pendidik di sekolah untuk benar-benar memahami masa penting anak, apa saja tugas perkembangannya pada masa-masa itu, untuk selanjutnya dapat dengan semaksimal mungkin mencukupi kebutuhan si anak agar seluruh potensinya terbina. Termasuk di dalamnya daya kreativitas anak.

JP. Guilford menjelaskan dua model cara berfikir: yaitu konvergen dan divergen. Cara berfikir ini terkait dengan teori belahan otak (hemisphere theory), yaitu pembagian kerja/fungsi otak kanan dan otak kiri. Fungsi otak kanan (right hemisphere) berkenaan dengan pekerjaan yang bersifat non linier, non verbal, holistik, humanistis, kreatif, mencipta, mendisain, bahkan terkait magic/ mistik dan sebagainya. Sementara otak kiri (left hemisphere) berfungsi pada pekerjaan yang bersifat ilmiah, kritis, linier, teratur, sistematis, terorganisir, dan sebagainya. ${ }^{9}$ Dari pembagian fungsi dan kemampuan kerja otak ini disimpulkan bahwa cara kerja otak kanan lebih divergent, bersifat menyebar. Sedangkan cara kerja otak kiri lebih convergent, bersifat pemusatan fokus/terarah. Konvergen adalah cara berfikir yang biasa mengulas apa yang sering difikirkan orang lain secara kebanyakan. Sementara berfikir divergen adalah kebalikannya, ia memikirkan apa yang jarang difikirkan. Dalam kaitannya dengan daya kreatif maka cara berfikir divergentlah yang dianggap lebih mampu berkreativitas.

Sedangkan jika dilihat dari psikoanalisa, Freud dan para pengikutnya memandang kreativitas adalah sebagai sublimasi dorongan seksual atau libido. Sehingga dimaknai, orang yang memiliki daya kreativitas yang bagus adalah mereka yang mampu me-

\footnotetext{
9 Selengkapnya di: Clark B. Growing Up Gifted, (Ohio: A Bell and Howell Information Company, 1983)
} 
manage tingkat libidonya. ${ }^{10}$ Mereka yang memiliki daya kreativitas yang baik, terkadang melakukan tindakan dan mempunyai pemikiran yang acapkali spontas, di luar dugaan orang lain, sehingga kadang tidak bisa dijelaskan dengan nalar ilmiah. Setelah mempelajari daya kreatrivitas dalam sains, Arthur Koestler menyimpukan bahwa, cara berfikir yang kaku dalam penemuan ilmiah adalah terlalu berlebihan, karena daya kreavitas di mata Koestler adalah sesuatu yang tidak bisa dijelaskan secara ilmiah. ${ }^{11}$

Dari cara-cara berfikir orang-orang yang memiliki daya kreativitas, yang lompatan imajinasinya kadang tidak terduga oleh orang lain, dimana ia biasanya meng-ide-kan sesuatu yang tidak terfikirkan oleh orang lain, maka secara inheren kreativitas seperti mengisyaratkan "kejeniusan" dalam pola kerjanya. Pada tahun 1700-an, jenius dipahami sebagai sebuah daya yang tidak bisa dipahami secara ilmiah, dan misterius dalam menghidupkan aspek-aspek insani, sedangkan saat ini, jenius dipahami sebagai kemampuan luar biasa untuk mencapai orisinalitas yang diinginkan atau pada orang yang memberikan kontribusi baru dan berguna bagi kemanusiaan. ${ }^{12}$

Apabila ditekankan pada ide ini, yaitu sisi jenius yang berlindung di balik daya kreativitas, akan muncul pemahaman bahwa kreativitas hanya bisa dimiliki oleh orang-orang jenius. Orang yang memiliki tingkat IQ istimewa yaitu sekitar 150-200. Maka ide ini akan bertentangan dengan pemaknaan kreativitas oleh pakar-pakar yang sebelumnya sudah disebutkan, yaitu Torrance, Drevdahl, Barron, Utami dan Rhodes, mungkinpun oleh banyak pakar lain yang tidak disebutkan di sini. Sedangkan para pakar tersebutpun memberikan definisi seperti itu setelah melalui pengujian hipotesa dan serangkaian penelitian dengan metodologi yang sah. Lalu dimana titik temunya?

Psikoterapi menjawabnya dengan menjabarkan dua kondisi yang bersebrangan, yaitu yang mendukung tumbuhnya daya kreativitas, dan kondisi yang menghalanginya, dimana dua kondisi ini dibahas dari segi internal dan eksternal individu. ${ }^{13}$

Kondisi yang mendukung tumbuhnya kreativitas dari segi internal adalah, penerimaan diri pada fenomena baru, mengurangi penolakan diri dan pertahanannya, responrespon yang tidak biasa, disiplin diri, penghargaan diri yang tidak berlebihan, minat yang luas, penolakan-penolakan hambatan yang datang dari luar, kemampuan untuk membuat penyaluran kapasitas, dan kemampuan untuk berimprovisasi, dan mendramatisir. Sedangkan dari segi eksternalnya, kondisi yang penuh permainan, tidak terlalu kompetitif,

10 Carl Gustav Jung, Modern Man in Search of a Soul, (New York: Harcourt Brace \& World, 1962), hlm.

${ }^{11}$ Lihat di: Arthur Koestler, the Act of Creation, (New York: Dell, 1964), hlm. 176-177

${ }^{12}$ Silvano Arieti, Creativity, (New York: Basic Books, 1986), hlm. 293-294

${ }^{13}$ Lihat di: Vance Peavy, Therapy and Creativity: A Dialogue, (New York: Basic Books, 1989,) hlm. 60-72 
tidak rapat dengan penilaian, memberikan motivasi situasional, tidak ada batasan waktu, percaya, bersifat personal, dan berorientasi proses.

Sebaliknya, kondisi yang menghambat tumbuh kembang kreativitas dari segi internal adalah, perhatian berlebihan pada opini yang lain, keterlibatan berlebihan dengan orang lain, penilaian sikap, membekunya tingkah laku menjadi pola-pola yang kaku dan tingginya rasa takut. Dari sisi eksternalnya yang menghambat lajunya kreativitas adalah tekanan sosial untuk menjadi konformis, batasan waktu, penilaian yang terlalu ketat, tekanan penampilan, disiplin yang berlebihan, serta kurangnya apresiasi bahkan hukuman berlebihan yang diberikan terhadap munculnya sikap-sikap atau ideide kreatif.

Kubie, di sisi lain dari psikotherapy, membandingkan proses kreatif dengan neurotic/ neurose. ${ }^{14}$ Baginya, inti dari jiwa yang sehat adalah fleksibilitas dalam berbagai cara vital, sedangkan inti dari sakit adalah menyimpan tingkah laku yang tidak dapat diubah, dan pola-pola yang tidak pernah terpuaskan. ${ }^{15}$

Secara lebih jauh makna dari pemahaman Kubie ini adalah, orang yang sehat jiwanya adalah orang yang mampu melenturkan pemikirannya dalam menghadapi kesulitan. Penulis mengidentikkan pemahaman ini dengan kemampuan kreativitas yang didefinisikan Torrance. Bahwa, kreativitas adalah kemampuan seseorang untuk mencari solusi yang tepat ketika berhadapan dengan kesulitan. Apabila saraf melentur, kondisi jiwa bisa fleksibel menghadapi tekanan, maka ia akan -seperti karet- elastis. Dimana elastis tidak mudah putus. Jika disandingkan dengan teori toleransi stres dalam ilmu Fisika, bahwa toleransi stres adalah suatu keadaan benda berupa kawat atau tali, yang menahan benda lain di atasnya yang jauh lebih berat. Ketika itu, ia akan melengkung, dan toleransi stres adalah waktu (seberapa lama) kawat melengkung mampu menahan beban berat, sebelum akhirnya putus. Ketika kawat kian melengkung, mungkin pula meregang karena beratnya beban, ini bisa disamakan dengan kondisi seseorang yang sedang menanggung beban mental yang hebat, sehingga mengalami gangguan neurose. ${ }^{16}$ Sedangkan apabila kawat tidak mampu lagi menahan berat benda, maka kawat akan putus, dengan kata lain, jika saraf tidak mampu lagi menanggulangi dan menampung persoalan, maka saraf akan putus. Pada beberapa orang ini akan berakibat stroke, dan pada sebagian lain ini akan berakhir di psikose, yaitu sakit jiwa.

${ }^{14}$ Zakiah Darajat mengelompokkan ketidakstabilan mental/emosional ke dalam psikose dan neurose. Psychose semata-mata adalah sakit jiwa atau gila, sedangkan neurose/gangguan jiwa mencakup kecemasan/anxiety, ketakutan/fear, ketakutan terhadap sesuatu karena trauma/phobia, tidak bisa tidur/insomnia, kepribadian kembar/double personality, histeris/hysteria, berjalan dalam tidur/fatigue. Lihat selanjutnya: Zakiah Daradjat, Kesehatan Mental, (Jakarta: Penerbit Kwitang, 1996), cet. Ke 23, hlm. 33-40

${ }^{15}$ Lihat di Kubie, L. Neurotic Distortion of the Creative Process, (University of Kansas Press, 1970)

16 Lebih jauh di: Tay Swee Noi and Peter J. Smith, Managing Stress: Guide To Asian Living, (Tokyo: Mr. Grow Hill Inc, 1990), hlm. 3-4 
Jiwa mengalami neurose karena ia tidak mampu merubah persepsinya tentang suatu keadaan yang menyakitinya, tidak mampu mengganti sudut pandang pemikiran terhadap keadaan yang menimpa, dan jiwa yang demikian, menyimpan ketidakpuasan yang sangat tingi terhadap hidup. Itulah yang melatarbelakangi definisi singkat yang dikatakan Kubie, bahwa inti rasa sakit adalah menyimpan tingkah laku yang tidak berubah dan pola-pola yang tidak terpuaskan. Maka sakit yang dipahamkan Kubie disini bukanlah pada wilayah fisik melainkan psikis, yaitu self, mind and soul.

Kembali pada psikoterapi, Lynn Wilcox mengatakan bahwa manusia dan semua yang ada di alam raya ini adalah hasil kreativitas Tuhan. Tidak ada daya manusia sedikitpun untuk bisa berkreativitas selain menggunakan daya yang diberikan oleh Tuhan, dan itu terjadi melalui ketersambungan yang kuat antara manusia dengan Tuhan. ${ }^{17}$ Ini sangatlah selaras dengan keyakinan yang diajarkan Islam, bahwa tiada kekuatan kecuali dari Allah yang maha tinggi lagi maha besar. Kekuatan yang dimaksud, adalah kekuatan apa saja, semua jenis kekuatan, baik itu fisik apalagi psikis. Berarti jika manusia ingin menjadi kuat jiwa raganya selain ia harus mengusahakannya dengan kemampuannya, ia harus menjalin koneksi yang intens dengan Tuhannya, karena hanya Tuhannya-lah yang mampu memberikan kekuatan tersebut kepada manusia. Agar manusia memiliki kekuatan untuk berbuat, untuk berkreativitas maka ia harus membuka mata hatinya terhadap Tuhannya, mendekat, sangat mendekat. Demikianlah gambaran yang dipaparkan Wilcox dalam psikoterapinya, bahwa ketersambungan dengan tuhan adalah inti daya untuk berbuat apa saja, inti dari kreativitas. ${ }^{18}$

Jika dari awal, dirunutkan, maka poin-poin penting dari kreativitas semakin bertambah, mulai dari unsur pembelajaran, proses, pengalaman, motivasi lingkungan, adaptasi/respon terhadap permasalahan, pengembangan/aktualisasi diri, sampai pada unsur kejeniusan, bahkan psikotherapy terutama Wilcox memasukkan unsur kedekatan hubungan dengan Tuhan, sebagai pilar penting dari sebuah bangunan kreativitas.

Walaupun demikian, bertambahnya unsur penting yang harus ada dalam penumbuhan kreativitas, tidaklah bersebrangan maknanya satu sama lain. Semua pilar pokok tersebut saling berhubungan erat dan mendukung satu sama lain, bahkan apabila satu diantaranya absen, maka kreativitas tidak akan mudah tumbuh dengan baik, sebagaimana penjelasan lebih lanjut.

17 Lynn Wilcox adalah seorang Doktor yang berhasil menemukan inti sari ajaran sufi untuk psikoterapi Ia adalah guru besar Tasawuf di Universitas Wake Forest. Baginya sufistik Islam, lebih menawarkan obat yang jelas bagi kehampaan jiwa, karena sufistik menyambungkan manusia dengan Tuhannya, tidak sama dengan psikologi Barat yang mengkaji manusia sebatas tingkah laku dan daya-daya yang dimilikinya, tetapi melupakan sang Sumber daya yang memberi daya tersebut, yaitu Tuhan yang dibahasakan oleh Wilcox sebagai the Source. Begitu pula kreativitas sebagai salah satu daya manusia, yang tidak bisa dipisahkan dari ketersambungan manusia dengan Tuhannya. Lebih lengkap; Lynn Wilcox, Personality Psychotherapy, (terj.) (Yogyakarta: Ircisod, 2006), hlm. 185-189

${ }^{18}$ Lynn Wilcox, Personality Psychotherapy, (terj.) (Yogyakarta: Ircisod, 2006), hlm. 190 
Perjalanan pembelajaran mengenai segala sesuatu memerlukan proses. Bahkan Allahpun menciptakan alam ini melewati tahapan proses yang bisa diamati dalam alQur'an. Walaupun dalam ayat lain Allah mengatakan bahwa untuk penciptaan apapun Ia bisa saja hanya dengan mengucapkan “kun/jadi!" maka jadilah apapun yang dikehendakiNya (QS. Yasin [36]: 82). ${ }^{19}$ Namun Allah tetap menciptakan langit dan bumi dalam dua hari ${ }^{20}$ (QS. Fushshilat [14]: 9), yang demikian itu bertujuan untuk menjelaskan pada manusia bahwa penciptaan sesuatu memerlukan proses, walaupun sebenarnya Allah bisa menciptakannya seketika.

Maka dari itu, wajar apabila manusia memerlukan proses untuk sampai pada sesuatu, karena manusia tidak memiliki daya Kun fa Yakūn seperti Allah. Manusia harus belajar, manusia yang enggan belajar menurut Mahmud Qombar, bagaikan hewan yang bodoh, karena setiap orang biasa pasti memerlukan bimbingan orang lain yang lebih tahu untuk memberinya pengetahuan sehingga dirinya tidak tersesat. ${ }^{21}$ Untuk menjadi kreatif membutuhkan sebuah pembelajaran. Karena perubahan tingkah laku yang dicapai seseorang dari tidak bisa menjadi bisa, tidak tahu menjadi tahu, tidak kreatif menjadi kreatif tentunya melewati tahapan-tahapan pembelajaran, sebagai hasil dari proses kognitif yang dilakukan oleh individu atas dasar pengalaman dan interaksi dirinya dengan lingkungan sekitarnya.22

Menguasai pengetahuan yang biasa dipelajari orang lain, untuk menjadi "bisa" dalam hal yang biasa buat kebanyakan orang memerlukan proses belajar yang baik dan mencukupi syarat. Apalagi untuk memiliki daya yang "tidak biasa” yaitu kreativitas, seperti dikatakan bahwa kreativitas tidak bisa dijelaskan secara ilmiah. Dalam usaha menjadi kreatif, seseorang memerlukan lingkungan yang kondusif, yaitu lingkungan yang memotivasi. Walaupun individu memiliki minat belajar tinggi, sarana belajar memadai,

19 Kata kun di sini hanyalah sebatas illustrasi bahwa, dalam menciptakan apapun Allah tidak butuh bantuan alat, atau bantuan pihak lain. Allah hanya memerintahkan, maka sesuatu itu bisa langsung tercipta seketika, ada kyang langsung jadi secara keseluruhan, ada yang melalui proses. Namun Allah mampu menciptakan dengan hanya memerintah saja, dan kata kun hanyalah perumpamaan bagi manusia, sebatas ilustrasi. Selengkapnya baca: Untuk lebih jelas lihat: Quraish Shihab, Tafsir Misbah: Pesan, Kesan dan Keserasian Al-Qur'an, (Jakarta: Lentera Hati, 2006), vol. 11, hlm. 581

20 Kata dua hari, dalam al Qur'an tidak harus dipahami sama dengan 2x24 jam waktu manusia di bumi. Dalam bahasa arab, bahkan digunakan untuk menunjukkan lamanya periode sebuah kegiatan dilangsungkan, dan itu bisa bermakna lama atau sebentar, pendek atau panjang. Perlu diingat juga bahwa, satuan waktu manusia terkait dengan perjalanan rotasi bumi mengitari matahari. Ketika manusia keluar dari bumi maka satuan waktunya akan berubah. Seperti di planet Pluto yang terjauh dari matahari, memakan waktu selama 250 tahun waktu bumi. Oleh karenanya hari versi Allah ta'ala tidak bisa diukur dengan hari versi manusia. Lihat selanjutnya di Untuk lebih jelas lihat: Quraish Shihab, Tafsir Misbah: Pesan, Kesan dan Keserasian Al Qur'an, (Jakarta: Lentera Hati, 2006), Cet. ke-7,vol. 12, hlm. 382

21 Mahmud Qombar, Dirosat Turatsiyyah fi al-Tarbiyah al-Islamiyah, (Qatar: Dar al-Tsaqafah, 1405H/1985M), Jilid. ke-1, hlm. 337 hlm. 91

22 Muhibbin Syah, Psikologi Pendidikan; Suatu Pendekatan Baru, (Bandung: Remaja Rosdakarya,1995), 
potensi intelektual menunjang, namun lingkungan tidak mendukung, maka proses pembelajaran untuk menjadi/menguasai apapun tetap mengalami kemandegan, oleh karenanya faktor mileu adalah salah satu pilar penting bagi keberhasilan sebuah proses pembelajaran atau pendidikan apapun. ${ }^{23}$

Ketika individu sudah memulai untuk belajar yang didukung salah satunya dengan lingkungan yang memotivasi, maka sebuah proses pencarian kemampuan telah dimulai. Dalam proses ini, individu akan menemukan pengalaman-pengalaman baru tentang banyak hal. Pengalaman atau pemahaman baru terkadang tidak hanya timbul dari hasil belajar, dapat juga timbul dari usaha adaptasi individu terhadap perubahan, atau merupakan jawaban dari tuntutan masalah yang dialami. Pengalaman demi pengalaman akan membimbing individu untuk mendapatkan pengetahuan yang kian komprehensif tentang segala sesuatu. Proses pembelajaran yang melahirkan pengalaman ini membutuhkan kemampuan intelektual untuk mengurai dan menganalisa pengalaman-pengalaman yang didapatkan sehingga mampu memaknai informasi yang telah didapatkan dengan pemaknaan yang baru dan berbeda, namun tetap berguna. Atau bahkan memberikan sebuah pemahaman baru mengenai sesuatu.

Selain membutuhkan daya kognisi, diperlukan juga kepribadian yang matang, dimana ia dalam berfikir mencoba menemukan sesuatu itu, tidak lagi memikirkan keuntungan dirinya, namun untuk kemaslahatan orang lain. Individu bersedia menggunakan waktu dan kemampuannya semaksimal mungkin, untuk melakukan yang terbaik bagi sesamanya. Ia bersedia mengembangkan dirinya demi kepentingan orang lain. Hanya individu yang sudah memiliki kematangan pribadi yang mampu berlaku demikian. Itulah sebab mengapa Maslow meletakkan aktualisasi diri sebagai kebutuhan tertinggi dan terpisah dari kebutuhan dasar, karena walau semua manusia membutuhkannya namun tidak semua manusia mampu menggapainya. ${ }^{24}$

Demikianlah untuk memecahkan suatu masalah berat/penting, atau menjawab tuntutan terhadap sesuatu, individu menggunakan kematangan pribadinya dalam mengembangkan diri bagi kepentingan orang lain, pengalaman yang sudah didapatkannya untuk dicombine dengan daya intelektualnya yang tinggi sehingga bisa menemukan sesuatu yang baru, yang bisa disebut solusi. Pada tahap ini, tingkat intelegensi seseorang dituntut untuk terlibat secara maksimal. Itulah yang mendasari terselipnya ide jenius pada daya kreativitas seperti yang disebutkan sebelumnya. Karena untuk mampu memaknai sebuah informasi/fenomena dengan pemahaman yang berbeda, tidak mengikuti pemahaman sebelumnya, bahkan mampu memunculkan sudut pandang yang sebelumnya tidak pernah terfikirkan oleh orang kebanyakan, tentu membutuhkan analisa

23 Dzaatil Husni, Diktat Ajar Psikologi Umum, (Untuk internal STAI Darunnajah, 2009), hlm. 30

${ }^{24}$ Ibid., hlm. 45 
tinggi dengan tingkat intelegensi yang tidak rendah. Karena informasi ataupun fenomena yang diamati sama dengan yang diamati oleh orang lain, namun terjawantahkan melalui pola fikir yang berbeda sehingga hasilpun berbeda, melampaui batas pemahaman umum, bahkan kadang terlihat "lain".

Namun begitu, bukan berarti individu yang tingkat intelegensinya sedang kemudian tidak mampu berkreasi atau tidak memiliki daya kreativitas sama sekali, karena seperti sudah dijabarkan bahwa kreativitas bukan given by God, walaupun sumbernya memang dari God/the Source. Karena daya kreativitas bukanlah sesuatu yang dibawa dari lahir laksana DNA. Ianya bisa dipelajari dan diusahakan, walaupun mungkin akan ada perbedaan antara individu yang berintelegensi sangat tinggi dengan yang hanya "tinggi" atau bahkan di bawah itu.

Lalu apa hubungannya kreativitas dengan segala unsur pembangunnya, itu dengan kedekatan kepada Tuhan? Perlu diingat bahwa manusia terlahir dengan fitrahnya masingmasing. Fitrah bisa disandingkan maknanya dengan potensi. Dalam Islam manusia dikenal memiliki potensi untuk belajar. Dalam al-Qur'an, manusia kadang disebut dengan istilah nas (bentuk tunggal)/insan (bentuk jamak), Kata insan berasal dari kata al-uns, anisa, nasiya dan anasa, dapat dikatakan bahwa kata insan menunjuk suatu pengertian adanya kaitan dengan sikap, yang lahir dari adanya kesadaran penalaran ${ }^{25}$ Kata insan digunakan al-Qur'an untuk menunjukkan kepada manusia dengan seluruh totalitasnya, jiwa dan raga. Manusia yang berbeda antara seseorang dengan yang lain adalah akibat perbedaan fisik, mental, dan kecerdasan ${ }^{26}$. Apabila manusia dikatakan bisa berbeda seorang dengan lainnya karena salah satu faktornya adalah kecerdasan, berarti manusia memiliki tingkat intelegensi yang berbeda seorang dengan yang lainnya. Berarti pula manusia memiliki potensi belajar. Walaupun tingkat intelegensi dan kemauan serta kemampuan belajar bukan satu-satunya yang mempengaruhi kecerdasan. Tersirat pula dalam beberapa ayat al-Qur'an yang kerap diakhiri dengan kata-kata "apakah kamu tidak berfikir?" "apakah kamu tidak berakal?". Kata-kata ini menunjukkan bahwa akal dan potensi untuk belajar dan diajar telah diberikan Allah, tetapi manusia kurang memaksimalkannya atau bahkan dinilai Allah tidak memanfaatkannya.

Karena otak sebagai organ berfikir dan akal sebagai kemampuan berfikir adalah pemberian Allah, juga willing untuk belajar juga dianugrahi Allah, maka sudah seharusnya manusia apabila ingin memaksimalkan daya kerja otaknya, mendekatkan diri secara lebih kepada Tuhannya. Sebuah ibarat yang umum dalam kenyataan hidup sehari-hari, jika seorang bawahan ingin mendapatkan kenaikan gaji/kenaikan pangkat dari atasan hendak-

25 Musya Asy'arie, Manusia Pembentuk Kebudayaan dalam al-Qur'an, (Lembaga Studi Filsafat Islam, 1992), hlm. 22

26 M. Quraish Shihab, Wawasan al-Quran, (Bandung: Mizan,1996), hlm. 280 
lah ia memperbaiki kinerjanya, memperbaiki etos kerjanya, memperbaiki sifatnya secara personal sebagai bawahan juga dalam relasinya dengan sesama karyawan, apalagi dengan atasan. Karena kenaikan gaji/kenaikan pangkat adalah nilai plus yang belum tentu bisa didapatkan bawahan lainnya. Demikianlah kiranya dengan kreativitas, karena daya kreativitas adalah nilai plus bagi cara kerja akal sebagai kemampuan berfikir, yang tidak semua orang memilikinya sehingga untuk mendapatkannya, hendaklah mengadakan pendekatan yang intens dengan Sang Sumber kreativitas itu sendiri. Dari penjelasan ini sekiranya bisa diketahui titik temu semua pilar-pilar pembangun rumah "kreativitas".

\section{Kreativitas pada Anak}

Perkembangan kreativitas pada umumnya mengikuti pola-pola yang dapat diramalkan, mulai dari tahap awal perkembangan anak, dunia bermainnya sampai pada tahapan selanjutnya kettika ia dewasa. Karena kreativitas merupakan bagian dari perkembangan kognisi maka kreativitas dapat ditinjau dari perkembangan kognitif, berdasarkan teori kognitif Jean Piaget. Menurutnya ada empat tahapan perkembangan kognitif, yang dalam penjelasan berikut juga akan dijabarkan dari segi perkembangan kreativitasnya, termasuk proses belajar, pengaruh mileu, dan penanaman jiwa keagamaan, yaitu:27

\section{Tahap Sensori Motoris}

Tahap ini dimulai dari kelahiran sampai usia 2 tahun, dimana anak belajar dan berusaha mencapai kematangan dalam memfungsikan saraf sensori motoris, yaitu saraf yang ada pada tangan, kaki dan seluruh persendian. Mampu berlari, walau tidak kencang adalah target yang seharusnya mampu dicapai anak pada saat umurnya 2 tahun. Pada tahap ini, interaksi anak dengan mileunya masih terpaku sekitar keluarga, terutama keluarga inti, atau orang yang satu rumah dengannya. Interaksi dengan lingkungan lebih berorientasi pada gerakan otot-otot dan saraf motoriknya, ia suka menyentuh dan memegang sesuatu dengan erat, dan lebih cenderung tergantung dari stimulus dari lingkungannya. Apabila orang tua dan keluarga dekatnya sering menstimulasi untuk berjalan maka kemampuan berjalannya akan lebih cepat dikuasai dibandingkan anak yang kurang mendapat stimulasi.

Mengenai kreativitas, ${ }^{28}$ piaget menjelaskan pada usia ini, kemampuan berkreasi masih nol, karena semua kegiatannya hanya berorientasi fisik yang bersifat refleksif, karena pandangannya terhadap objek masih belum permanen, mudah dialihkan. Ia

27 Lebih lengkap di: Mc Cormak, A.J. Piagetian Theory and the Development of Creative Thinking, (Ohio: Charles E. Merril, 1982).

28 Lebih jauh di; Bybee R.W. and R.B. Sund, Piaget for Educators, (Ohio: Charles E. Merril, 1982). 
belum mengenal konsep ruang dan waktu, konsep tentang dirinya dan hubungan dengan orang lain, sehingga belum mampu menciptakan sesuatu.

Sedangkan untuk penanaman jiwa keagamaan, dalam pandangan Woodworth, bayi telah memiliki insting keagamaan diantara sekian insting yang dimilikinya, hanya saja seluruh indra dan organ berfikirnya belum mencapai kematangan fungsi, sehingga nilainilai keagamaan belum mampu ditangkap ataupun dinalarnya. ${ }^{29}$ Karena bayi memiliki insting keagamaan, yang memang telah diketahui dalam Islam, bahwa tiap bayi lahir dengan fitrahnya, dan setiap manusia memiliki fitrah atau berpotensi untuk bertuhan dan beragama, Nabi mensunatkan seorang bapak untuk mengazankan putra atau membisikkan iqamat di telinga putrinya ketika lahir. Selanjutnya yang bisa dilakukan orang tua adalah membiasakan anak dengan situasi yang agamis, atau mendengar katakata pujian seperti tahmid, tahlil dan sebagainya. Misalnya dibawa berzikir setiap selesai shalat jama'ah. Ketika akan menyuapi anak, ibunya terlebih dahulu membaca doa mau makan. Ketika anaknya bersin, orang tua yang menyebut kalimat tahmid. Saat akan memandikan, mengenakan baju, menyusui, atau menggendongnya, dahulukan dengan menyebut lafadz basmalah, dan cara-cara lainnya.

\section{Tahap Pra Operasional}

Tahap ini berlangsung dari usia 2-7 tahun, disebut juga tahap intuisi karena perkembangan kognisinya memperlihatkan kecendrungan yang ditandai oleh situasi intuitif. Ini disebabkan perbuatannya tidak didasari pertimbangan rasional melainkan didorong oleh perasaan, kecendrungan alamiah, peniruan sikap-sikap yang didapat dari orang yang bermakna, serta lingkungan sekitarnya. Anak bersifat egosentris di usia ini, yang dalam pandangan Kartono, berbentuk naif. ${ }^{30}$ Karena sifatnya itu, ia sering bertentangan bahkan dengan orang tuanya, yang diistilahkan sebagai masa Trotzalter (penentangan) pertama, ${ }^{31}$ karena ia lebih belajar untuk mengikuti kemauan dan perasaannya.

${ }^{29}$ Jalaluddin, Psikologi Agama, (Jakarta: Raja Grafindo Persada, 2007), hlm. 65

30 Egosentrisme adalah sifat yang berorientasi kepada kepentingan dan kepuasan pribadi, sehingga untuk itu sering memanfaatkan orang lain, menginginkan orang lain berbuat menurut kehendaknya, namun naïf yang ditambahkan Kartono, adalah karena anak pada dasarnya tidak bermaksud seegois itu. la bersikap egois karena memang belum mengerti bagaimana seharusnya bersikap, dank arena ia memang belum mampu untuk menenggang rasa. Jadi egoismenya terbentuk diluar kesengajaannya. Lihat selanjutnya di; Kartini Kartono, Psikologi Perkembangan Anak, (Jakarta: CV Mandar Maju, 1995).

31 Dikatakan penentangan karena anak dengan segala caranya, dan hamper dal;am segala hal berlaku di luiar norma dan tata cara yang disukai orang tuanya, sehingga muncul konflik-konflik kecil yang berujung pada kemarahan orang tua dan sikap anak yang merajuk, melawan atau bahkan menangis, dan ini merupakan sesuatu yang wajar, karena anak belum mengerti akan kepatuhan terhadap orang tua dan tata nilai yang berlaku dalam kehidupan keluarganya. Selengkapnya baca:, FJ. Monks, AMP Knoers, Siti rahayu Haditono, Psikologi perkembangan (pengantar dalam berbagai bidangnya, (Yogyakarta: Gajah Mada University Press, 2004). 
Daya kreativitas pada usia ini sudah mulai tumbuh karena anak sudah memiliki memory, mulai memahami keterkaitan ruang dan waktu walaupun secara sederhana, mampu memikirkan masa lalu dan masa datang sesuai kemampuan imajinasi dan kekuatan memori serta daya tangkapnya, meskipun rentang waktu yang diingat dan difikirkannya masih sangat pendek. Selain itu, anak memiliki kemampuan untuk menterjemahkan fenomena alam dan sesuatu yang ada di lingkungannya secara animistik dan antropomorfik ${ }^{32}$ Animistik adalah menjelaskan fenomena alam dengan menggunakan perumpamaan hewan. Sementara antropomorfik adalah menjelaskan fenomena alam dengan perumpamaan manusia. ${ }^{33}$ Seperti misalnya ketika seorang gadis kecil say bye kepada bunga-bunga, ia membayangkan bunga tersenyum kepadanya.

Kemampuannya ini akan tumbuh dengan baik apabila mileu-nya mendukung, misalnya orang tua memasukkan anak ke kelompok play group/TK yang berkualitas, dan di rumah keluarga juga rajin memberikan stimulasi dengan memberikan mainan-mainan yang menunjang kreativitas dan meningkatkan daya imajinasi anak, sembari mengamati perkembangan dan arah minat anak. Kemampuan imajinasi pada anak-anak merupakan kemampuan dasar kreativitas. Tanpa adanya imajinasi yang melampaui pemahaman umum, sebuah hal baru akan sulit tercipta, seperti halnya penemuan sepeda, pastilah diawali dari angan-angan untuk bisa berjalan dengan menaiki sesuatu agar bisa lebih cepat sampai di tujuan dibanding dengan berjalan kaki.

Untuk bidang keagamaan, pada usia ini menanamkan agama pada anak bisa dilakukan dengan dongeng, Ernest menyebut masa ini dengan the Fairy Tale Stage. ${ }^{34}$ Daya fantasinya yang sangat tinggi bisa dimanfaatkan untuk mengenalkan konsep kekuasaan Tuhan melalui dongengyang dikarang, walaupun kurang masuk akal.

\section{Tahap Operasional Konkret}

Mulai usia 7-11 tahun perkembangan kognitif anak memasuki tahap konkret, karena anak mulai memahami realita yang terjadi di sekitarnya, sehingga ia mulai belajar untuk objektif, egoisnya berkurang, mulai bisa memahami fikiran dan perasaan orang lain, walaupun tidak sepenuhnya.

Mengenai kreativitasnya, ${ }^{35}$ pun sudah mulai berkembang, karena daya imajinasinya tetap tinggi sedangkan konsep ruang dan waktu yang ada di fikirannya makin terbentuk dengan sempurna. Sebagai contoh, sebuah lomba menggambar pernah diadakan untuk

32 Lebih jauh di; Bybee R.W. and R.B. Sund, Piaget for Educators, (Ohio: Charles E. Merril, 1982)

33 Mohammad Ali, Mohammad Asrori, Psikologi Remaja: Perkembangan Peserta Didik, (Jakarta: Penerbit Bina Aksara, 2005),, hlm. 48

34 Ernest Harms, The Development Of Religious on Children, (Ohio: Charles E. Merril,1988)

35 Lebih jauh di; Bybee R.W. and R.B. Sund, Piaget for Educators, (Ohio: Charles E. Merril, 1982) 
menghibur anak-anak penghuni penampungan korban Tsunami Aceh yang terjadi tahun 2006. Peserta lomba adalah anak-anak yang masih di usia SD, berarti tidak lebih dari 12 tahun. Dari semua gambar yang masuk, 90\% diantaranya adalah gambar air yang menggenang begitu luas, dan gambar rumah atau hanya atap rumah yang hancur terseret arus. Beberapa anak yang kehilangan keluarganya bahkan menggambar ayah dan ibu atau kakaknya dalam posisi tidur, diantara genangan air (seakan terbawa Tsunami). Kesemua itu mengilustrasikan terjadinya Tsunami, padahal lomba diadakan setelah berbulan-bulan pasca Tsunami. Lomba menggambar itu menjadi penyaluran kreativitas mereka, yang didasari oleh pengalamandan memori, bahkan tersalurkan juga perasaan mereka walaupun ketika menggambar tidak lagi meneteskan air mata karena kemampuan mereka menyadari realita sudah semakin berkembang.

Mileu tetap memegang peranan penting, dan ini terlihat pada lomba menggambar ini, dimana kreativitas mereka dipengaruhi oleh stimulus yang mereka dapatkan dari kejadian di lingkungan. Dalam usaha membangkitkan jiwa agama anak, di usia ini mulai bisa dikenalkan konsep Tuhan secara lebih mendekati kebenaran seperti yang diajarkan agama. Karena kemampuan akal yang sudah bisa memikirkan realitas, atau the Realistic Stage, dalam istilah Ernest.

\section{Tahap Operasional Formal}

Setelah 11 tahun, untuk selanjutnya kemampuan kognisi anak memasuki tahap operasional formal. Kemampuannya berfikir logis hampir menyertai seluruh perbuatannya. Aspek moral dan sensitivitasnya terhadap dunia luar semakin berkembang baik. Ia belajar memisahkan antara rasio dan perasaannya. Walaupun ia tidak selalu berbuat rasional, karena pada masa remaja. Sekitar usia 15-18 tahun, anak akan memasuki masa Strung and Drum, yaitu masa yang penuh dengan kegoncangan, ketidakstabilan emosi, yang kadang mengaburkan pemikiran rasional yang awalnya telah mulai dimiliki. ${ }^{36}$

Untuk sisi kreativitasnya, masa-masa ini merupakan masa yang potensial dan kondusif untuk menumbuhkembangkan kreativitas sampai tingkat yang lebih tinggi. Seiring dengan relasi sosial yang sangat meluas, bukan hanya dekat rumah atau sebatas teman sekolah, namun jauh lebih dari itu, apalagi dengan adanya tekhnologi internet yang menyediakan media seperti friendster, facebook, twitter dan semacamnya yang menstimulasi anak melanglang jauh dari dunia keluarga. Mileu pergaulan anak yang sangat jauh meluas dari sebelumnya akan memberikan banyak pengaruh dan tidak selamanya pengaruh itu negatif ataupun positif sifatnya. Dari perkembangan relasi, akan timbul ide-

36 Masa remaja diistilahkan dengan trotzalter kedua, setelah trotzalter pertama yaitu usia 2-7 tahun. Baca lebih lengkap di: Syamsu Yusuf LN, Psikologi Perkembangan Anak dan Remaja, (Jakarta: CV Rosda Karya, 2002) cet. Ke-3. Lihat juga FJ. Monks, AMP Knoers, Siti rahayu Haditono, Psikologi Perkembangan: Pengantar dalam Berbagai Bidangnya, (Yogyakarta: Gajah Mada University Press, 2004). 
ide baru. Misalnya ide nge-band, atau mencari kerja sampingan di luar sekolah (yang positif) tanpa sepengetahuan orang tua untuk membantu ekonomi keluarga.

Karena pada masa ini, anak sudah mulai mampu memikirkan hal yang abstrak, yang terus berkembang, maka anak sudah bisa memahami nilai agama yang lebih abstrak, seperti nilai-nilai ibadah yang dijelaskan agama, konsep pahala dan dosa, surga dan neraka, serta konsep-konsep abstrak lainnya yang ada di dalam agama. Ernest menyebut masa ini dengan the Individual Stage.

Demikian penjelasan teori kognisi dan kreativitas Jean Piaget yang disertai analisa dari sisi proses belajar, pengaruh mileu serta pendidikan agamanya. Jika dikembalikan pemikiran kepada unsur-unsur penting kreativitas yang telah disebutkan pada halaman 5 tulisan ini, maka terdapat unsur aktualisasi diri yang dipahamkan Maslow. Tidak adanya unsur ini bukan dikarenakan teori Jean Piaget belum sempurna atau unsur kreativitas yang dipaparkan Maslow. Melainkan karena kemampuan intelegensi anak memang belum sampai ke tahap itu. Bahkan walau agama telah dikenalkan dari bayi, namun tetap belum menemukan bentuknya yang sempurna, baik dari segi pemahaman apalagi pengamalan. Zakiah Darajat mengatakan bahwa kematangan beragama seseorang biasanya dimulai pada usia 24 tahun, baru dimulai, dan masih akan terus berkembang, bergantung kepada banyak faktor yang mempengaruhi, dan tidak ada limit bagi kematangan beragama. ${ }^{37}$ Walaupun pada masa anak-anak sudah mengenal konsep Tuhan versi mereka karena diperkenalkan oleh orang tuanya, namun pemahaman utuh dan benar mengenai agama baru tumbuh ketika memasuki masa dewasa awal. ${ }^{38}$

Sejalan dengan kemampuan dan kematangan beragama, maka kematangan pribadi sampai akhirnya mampu mengembangkan diripun, bukan sesuatu yang muncul begitu saja, ia merupakan sesuatu yang muncul perlahan-lahan dan menemukan bentuknya yang sempurna ketika semakin dewasa, itulah sebabnya dalam teori kognisi dan daya kreativitas Jean Piaget yang dilengkapi analisa tentang proses belajar serta pengaruh mileu, tidak menyebutkan perkembangan keagamaan dan kematangan pribadi untuk mengaktualisasikan dirinya.

\section{Beberapa Langkah Menstimulasi Kreativitas Anak}

Setelah memahami kemampuan kognisi dan perkembangan daya kreativitas anak dari teori Jean Piaget, berikut dijelaskan sekilas tentang beberapa langkah menstimulasi perkembangan kreativitas anak.

37 Zakiah Darajat, Ilmu Jiwa Agama, (Jakarta: Bulan Bintang, 1970).

38 Pembagian tahapan kehidupan manusia dibagi ke dalam 10 tahapan berikut dengan developmental tasks dan psychosocial crises yang dialami pada setiap life stage. Dewasa awal umumnya dimulai dari usia 2230 tahun, dengan perbedaan yang tidak terlalu mencolok antar sesama psikolog. Lebih lengkap di: Newman \& Newman, Development Through Life: a Psychosocial Approach, (Illinois: The Dersey Press, 1979). 
Menstimulasi perkembangan anak bisa melalui cara bercerita, bermain, mendengarkan musik, dan melalui lukisan. ${ }^{39}$ Masing-masing cara tersebut memiliki poin-poin penting yang urgen untuk dimengerti oleh orang tua.

1. Melalui cerita. Cerita bisa disampaikan oleh guru di sekolah SD atau TK, dan bisa juga oleh orang tuanya pada waktu senggang, biasanya menjelang tidur malam. Dalam pemberian cerita, oleh siapapun hendaknya memperhatikan hal-hal berikut:

a. Pemilihan cerita yang cocok dengan tingkat intelegensi anak, seperti anak di bawah 7 tahun menyukai cerita tentang hewan, sedangkan usia 11 tahun sudah menyukai cerita tentang superheroes.

b. Ikatan emosional antara anak dengan yang menceritakan. Ini berpengaruh kepada situasi emosional juga terhadap penerimaan jiwanya akan nilai dari cerita yang dibacakan.

c. Efektivitas sarana, seperti penggunaan buku cerita bergambar bagi anak-anak. Karena anak masih menyukai dunia gambar.

d. Kemampuan pencerita, cerita tidak hanya dibacakan kemudian selesai. Pencerita juga memasukkan nilai-nilai positif yang terkandung dalam cerita, dengan perlahan, tidak terburu-buru dan sabar. Memahamkan nilai tidaklah dengan cara yang keras/mengomeli, tetapi dengan cara yang menarik hati, sehingga nilai cerita yang disampaikan bisa teringat dan mempengaruhi tingkah lakunya setelah itu. Pencerita harus pula menguasai intonasi bicara dalam bercerita ditambah mimik yang mendukung situasi yang diceritakan, sehingga membuat anak tertarik, senang mendengarkan cerita sampai selesai.

e. Menghargai dan menjawab pertanyaan yang dilontarkan anak tentang cerita tersebut dengan sabar, walau terkadang pertanyaan yang dilontarkannya terkesan bodoh. Karena bertanya pada dasarnya buka tanda ketidaktahuan melainkan tanda keingintahuan, karena itu harus diapresiasi, jika tidak akan menumbuhkan perasaan tidak nyaman antara anak dengan pihak yang bercerita

f. Menurut penulis, untuk kian mendekatkannya pada agama, hendaklah ia diceritakan kisah-kisah nabi dalam al-Qur'an, atau kisah-kisah orang shalih, atau sahabat nabi. karena banyak nilai moral dalam kisah-kisah itu, nilai-nilai yang akan mereka butuhkan untuk menjadi pribadi yang unggul. Tidak lupa memulai dengan basmalah, dan mengakhiri cerita menjelang tidur dengan hamdalah dan yang paling terakhir, doa menjelang tidur disusul cium sayang orang tuanya.

2. Melalui permainan. Ada banyak permainan di dunia anak, mulai dari permainan tradisional yang dimiliki tiap budaya suku, permainan yang didapatkan dari guru di sekolah mungkin pula yang diajarkan keluarga dan lingkungan, sampai permainan

${ }^{39}$ Secara garis besar tulisan ini diambil dari Amal Abdussalam Al Khalli, Mengambangkan Kreativitas Anak, terj. Hj. Umma Farida Lc., (Jakarta: Pustaka Al-Kautsar, 2006), hlm. 183-227 
modern yang tersedia di pasaran, seperti mobil-mobilan atau boneka dan semacamnya, di Timezone atau berupa game komputer. Dalam menawarkan permainan atau barang mainan kepada anak, hendaknya orang tua perlu mengetahui:

a. Sisi positif yang didapatkan anak dengan permainan/mainan itu

b. Pengaruh permainan/mainan terhadap tugas belajar yang tentu saja lebih pokok diselesaikan anak

c. Tingkat ketergantungan anak terhadap permainan/mainan tersebut

d. Model permainan yang disukainya dan tingkat kecintaannya pada permainan/ mainan tersebut, karena terkadang gejala penyimpangan orientasi seksual sudah muncul pada usia dini, ketika masa-masa bermain, hanya terkadang orang tua kurang mewaspadainya.

e. Menurut penulis, janganlah didekatkan anak pada permainan yang sedikit mengarah kepada judi, atau permainan negative lainnya, seperti main dengan taruhan uang, karena banyak sekali jenis permainan seperti itu saat ini. Pahamkan pada anak nilai negatif yang tersembunyi dalam permainan tersebut.

3. Melalui musik. Telah umum diketahui berdasarkan penelitian yang valid, bahwa alunan musik bisa merangsang fungsi tertentu dalam saraf otak kanan, sesuai teori belahan otak. Musik beralunan lembut seperti Mozart dan Bethoven diyakini bisa menstimulasi pertumbuhan otak bayi bahkan sejak di dalam kandungan, bukan hanya itu, segala jenis musik asal tidak terlalu keras baik untuk perkembangan otak bayi, juga termasuk shalawat Nabi Muhammad SAW yang dialunkan melalui kaset dan diperdengarkan ke perut ibu ketika mengandung, memberikan pengaruh pada peningkatan kecerdasan bayi setelah lahir.40 Untuk cara dengan musik ini, ada beberapa catatan penting:

a. Sebaiknya musik yang diperdengarkan adalah musik yang tidak keras atau hingar bingar, karena alunan musik yang sering didengar mempengaruhi kondisi jiwa bayi. Itu sebabnya sangat baik meninabobokkan anak dengan melantunkan asmaul husna atau shalawat Nabi, karena kalimat-kalimat indah itu lebih menenangkan jiwa anak dari pada alunan musik biasa, perlu diingat sekali lagi bahwa manusia adalah pancaran dari Zat Tuhan, maka ketika ia diingatkan dengan nama Tuhannya, alam bawah sadarnya akan mendengar dan jiwanya menjadi tenang, walau kenyataannya ia masih belum mengerti konsep Tuhan. ${ }^{41}$

b. Bersama anak menyanyikan lagu yang disukainya akan menguatkan tali kasih sayang anak dengan orang tuanya.

${ }^{40} \mathrm{http}: / /$ www.bobby-bola.com/info\%20ortu.htm, Info Orang Tua.

41 Dzaatil Husni, Diktat Ajar Psikologi Perkembangan, hlm. 25 
c. Arahkan anak untuk menyukai musik yang baik, apalagi dewasa ini anak-anak terkesan lebih cepat tumbuh dewasa daripada seharusnya yang didengarnya musik orang dewasa. Dimana lirik lagu yang dihafalnya adalah kata-kata yang bukan untuk konsumsi anak seusianya

d. Menurut penulis, sebaiknya orang tua mengajak anak menghafalkan asmaul husna dengan mengikuti irama lagunya, yang kini tersedia banyak dalam bentuk kaset dan MP3. Untuk ini, sebaiknya orang tua telah hafal lebih dulu, jikalau tidak, usaha ini akan lebih mudah untuk gagal, karena anak lebih melihat kepada apa yang dilakukan orang tuanya daripada mendengarkan apa yang dikatakan kepadanya.

4. Melalui lukisan. Melukis atau menggambar membangkitkan sisi kecerdasan anak yang lain. Karena melalui lukisan atau gambar ia akan mengembangkan imajinasinya, kemudian melenturkan jari-jarinya untuk membentuk sesuatu yang dikhayalkannya. Berarti saraf motorik jari tangan dan intelegensi terutama saraf pada otak kanan bekerja bersamaan. Ia melanglang buana ke alam imaginatif, menggunakan pengetahuan yang telah dimilikinya mengenai bentuk benda-benda atau tempat-tempat, bahkan lengkap dengan suasana tertentu, misalnya gedung sekolah lengkap dengan lapangan dan bendera merah putih, dengan suasana upacara bendera Senin pagi. Ia berspekulasi dengan nilai-nilai estetika versinya sendiri melalui ekspresi warna, yang mungkin kadang terlihat kacau oleh mata orang dewasa. Namun disitulah ia mereka-reka dan membangun sebuah seni, menuangkan daya kreativitas yang dimiliki, dan di atas semua itu, ia telah berusaha untuk mengekspresikan dirinya dengan cara terbaik menurutnya, dan ia berharap untuk diterima. ${ }^{42}$ Berkaitan dengan ini maka sebaiknya orang tua:

a. Memfasilitasi anak untuk menggambar/melukis. Walaupun tidak harus sampai mengikutkannya dalam kursus lukis.

b. Menghargai apapun yang digambarnya, dan memotivasi untuk hasil yang lebih baik. Kalaupun ada yang tidak baik dalam lukisannya tidaklah harus dikasari.

c. Memperhatikan kecendrungan objek gambar anak, karena apa yang digambarnya adalah apa yang dikhayalkannya, dan itu menunjukkan kecendrungan jiwanya ${ }^{43}$

d. Menurut penulis, sebaiknya saat anak menggambar, biasakan ia memulainya dengan basmalah, dan mengakhirinya dengan hamdalah, ketika ia menggambar pemandangan alam, hendaknya diceritakan kepadanya bagaimana kekuasaan Allah dalam menciptakan semua itu. Ketika anak berhasil menggambar sesuatu, apalagi apabila gambar tersebut benar-benar bagus, ingatkan anak untuk

42 Ibid., hlm. 50

${ }^{43}$ Ibid., hlm. 53 
mensyukuri nikmat Allah yang telah memberikannya kemampuan melukis dengan baik.

\section{E. Penutup}

Sedikit ulasan ini sekiranya menggambarkan bahwa penting bagi orang tua untuk membimbing anak dalam menemukan daya kreativitasnya. Karena tiap anak dilahirkan dengan tingkat intelegensi yang berbeda, sehingga orang tua tidak pernah tahu keistimewaan apa yang dimiliki anak apabila tidak distimulasi. Pun karena kreativitas bukan given by God, sehingga mestilah bisa dipelajari.

Walaupun anak memiliki kecenderungan bakat dan minat tertentu, namun hendaknya orang tua tetap mengarahkan anak ke jalan yang benar menurut agama, karena dunia hanya tempat singgah sementara, ada kampung akhirat yang lebih abadi untuk ditinggali, kendatipun demikian manusia tidak boleh melupakan nasibnya di dunia (Q.S. Al Qashash [28]: 77). Maka kewajiban orang tua menyiapkan anak untuk memiliki bekal menjadi manusia yang bermutu sesuai dengan kualifikasi mutu yang diminta dunia dan akhirat. Karena jika manusia ingin bahagia dunia akhirat hendaklah ia menguasai ilmu mengenai keduanya.

Sekali lagi, manusia adalah pancaran zat Allah, daya yang dimiliki manusia adalah God's blessing, maka untuk memiliki nilai plus dari daya yang telah diberikan, selain diusahakan dengan intelegensi, dibantu stimulasi dan motivasi lingkungan, di atas segalanya hendaklah individu membiasakan menjalin komunikasi yang intens dengan Penciptanya. Karena kreativitas bahkan daya apapun adalah bersumber dari the Source. Manusia tersambung dengan Tuhan seperti lampu tersambung dengan pemantiknya. Apabila pemantik tidak bersedia mengalirkan energi pada lampu, maka selamanya lampu akan redup.

"Hendaklah manusia membuka diri terhadap-Nya, berjalan di jalan-Nya, menyatu dengan-Nya, dan biarkan pola-pola Tuhan mengairi relung jiwa, niscaya akan terbuka segala keindahan, memahami keteraturan alam, untuk kemudian dimulainya ide-ide kreativitas yang berguna bagi umat dunia" 44 []

44 Disarikan dari Lynn Wilcox, Personality Psychotherapy, (Terj.) (Yogyakarta: Ircisod, 2006), hlm. 188- 


\section{DAFTAR PUSTAKA}

Alisyahbana, S. Takdir, (ed.) Kreativitas; Kumpulan Makalah Simposium Kreativitas Akademi Jakarta, Jakarta: PT. Dian Rakyat, 1983.

Arieti, Silvano, Creativity, New York: Basic Books, 1986.

Asrori, Mohammad, Mohammad Ali, Psikologi Remaja: Perkembangan Peserta Didik, Jakarta: Penerbit Bina Aksara, 2005.

Asy'arie, Musya, Manusia Pembentuk Kebudayaan dalam al-Qur'an, Lembaga Studi Filsafat Islam, 1992.

Barron, R. and R. Woods, An Introduction to Philosophy of Education, London: Methuen, 1982

Bybee R.W. and R.B. Sund, Piaget for Educators, Ohio: Charles E. Merril, 1982.

Clark B., Growing Up Gifted, Ohio: A Bell and Howell Information Company, 1983.

Darajat, Zakiah, Ilmu Jiwa Agama, Jakarta: Bulan Bintang, 1970. , Kesehatan Mental, Jakarta: Penerbit Kwitang, 1996.

FJ. Monks, AMP Knoers, Siti Rahayu Haditono, Psikologi Perkembangan: Pengantar dalam Berbagai Bidangnya, Yogyakarta: Gajah Mada University Press, 2004.

http://adesuryana.blogspot.com/2009/02/sejarah-sepeda.html

http://www.bobby-bola.com/info\%20ortu.htm, Info Orang Tua

Hurlock, Elizabeth, Child Development, Mc Graw Hill, 1978, $6^{\text {th }}$ ed

Husni, Dzaatil, Diktat Ajar Psikologi Perkembangan, Untuk internal STAI Darunnajah, Jakarta, 2009.

Husni, Dzaatil, Diktat Ajar Psikologi Umum, Untuk internal STAI Darunnajah, Jakarta, 2009. Jalaluddin, Psikologi Agama, Jakarta: Raja Grafindo Persada, 2007.

Jung, Carl Gustav, Modern Man in Search of a Soul, New York: Harcourt Brace \& World, 1962.

Khalli al, Amal Abdussalam, Mengembangkan Kreativitas Anak, (Terj. Hj. Umma Farida Lc.), Jakarta: Pustaka Al Kautsar, 2006.

Kartono, Kartini, Psikologi Perkembangan Anak, Jakarta: CV Mandar Maju, 1995.

Koestler, Arthur, The Act of Creation, New York: Dell, 1984.

Kubie, L. Neurotic Distortion of the Creative Process, University of Kansas Press, 1980.

Maslow, Abraham, Motivation and Personality New York: Harper, 1945. 
Mc Cormak, A.J. Piagetian Theory and the Development of Creative Thinking, Ohio: Charles E. Merril, 1982.

Munandar, Utami, Mengembangkan Bakat dan Kreativitas Anak Sekolah, Jakarta: Gramedia Widiasarana Indonesia, 1992.

Newman \& Newman, Development Through Life: a Psychosocial Approach, Illinois: The Dersey Press, 1979.

Noi, Tay Swee and Peter J. Smith, Managing Stress: Guide To Asian Living, Tokyo: Mr. Grow Hill Inc, 1990.

Peavy, Vance, Therapy and Creativity: A Dialogue, New York: Basic Books, 1989.

Qombar, Mahmud, Dirasat Turatsiyyah fi al-Tarbiyah al-Islamiyah, Qatar: Dar al-Tsaqofah, 1405H/1985M.

Shihab, Quraish, Wawasan al-Quran, Bandung: Mizan, 1996. 2006.

Tafsir Al Mishbah: Pesan, Kesan dan Keserasian Al-Qur'an, Jakarta: Lentera Hati,

Syah, Muhibbin, Psikologi Pendidikan; Suatu Pendekatan Baru, Bandung: Remaja Rosdakarya, 1995.

Torrance, E. P., The Faces and Forms of Creativity, Buffalo: Creative Educational Foundation, 1981.

Wilcox, Lynn, Personality Psychotherapy, (terj.) Yogyakarta: Ircisod, 2006.

Yusuf, Syamsu LN, Psikologi Perkembangan Anak dan Remaja, Jakarta: . Rosda Karya, 2002. 